\title{
When We See Us: Coming 2 America and the Intricacies of Black Representation and Diasporic Conversation
}

\author{
Terri Bowles \\ School of Media Studies, The New School, New York
}

Follow this and additional works at: https://digitalcommons.uri.edu/mgdr

Part of the Africana Studies Commons, Anthropology Commons, Economics Commons, Feminist, Gender, and Sexuality Studies Commons, Film and Media Studies Commons, Marketing Commons, Other Business Commons, and the Sociology Commons

\section{Recommended Citation}

Bowles, Terri (2021) "When We See Us: Coming 2 America and the Intricacies of Black Representation and Diasporic Conversation," Markets, Globalization \& Development Review. Vol. 6: No. 1, Article 3.

DOI: 10.23860/MGDR-2021-06-01-03

Available at: https://digitalcommons.uri.edu/mgdr/vol6/iss1/3

This Media Review is brought to you for free and open access by DigitalCommons@URI. It has been accepted for inclusion in Markets, Globalization \& Development Review by an authorized editor of DigitalCommons@URI. For more information, please contact digitalcommons-group@uri.edu. 
When We See Us: Coming 2 America and the Intricacies of Black Representation and Diasporic Conversation

\section{Markets, Globalization \& Development Review}
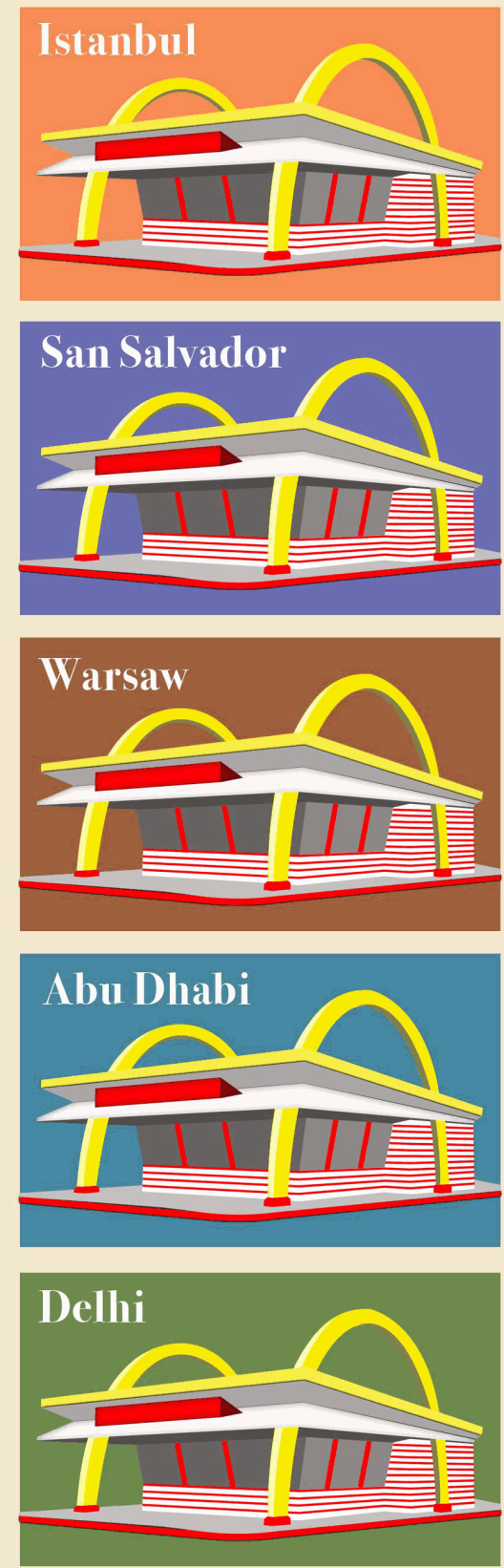
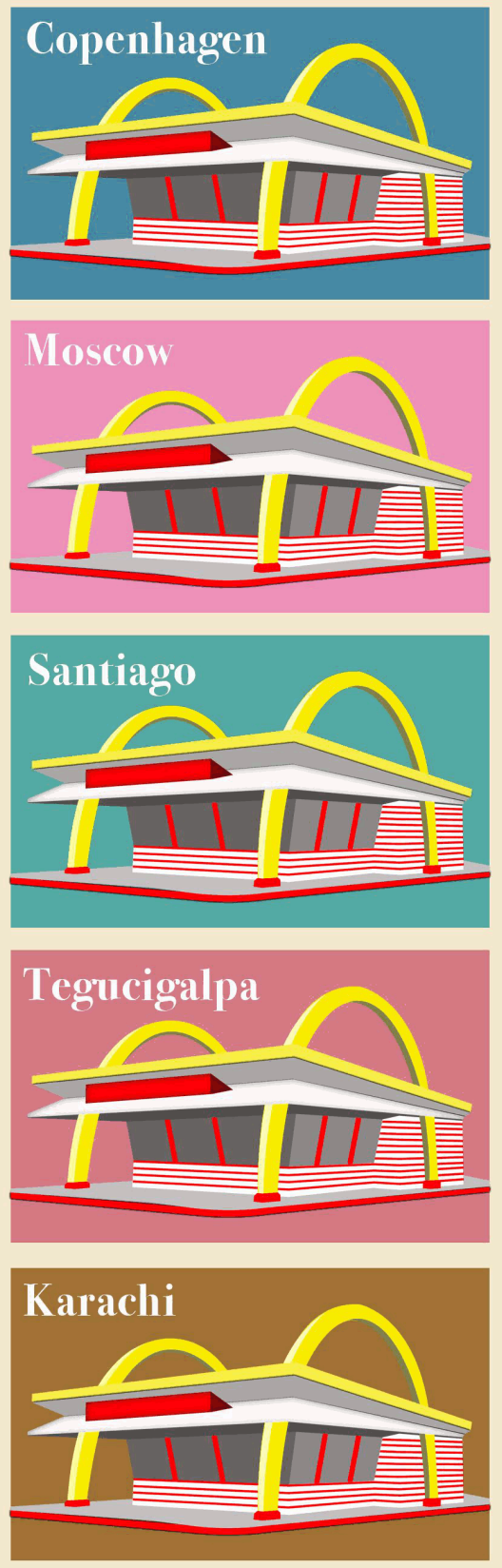
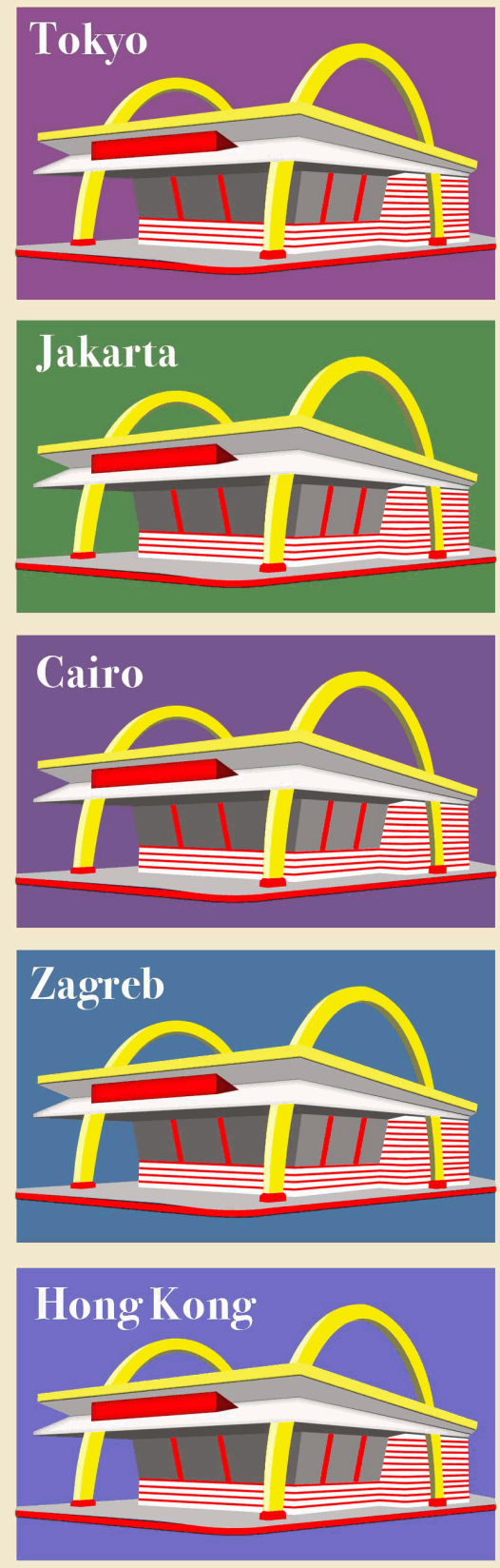

This media review is available in Markets, Globalization \& Development Review: https://digitalcommons.uri.edu/ $\mathrm{mgdr} / \mathrm{vol} 6 / \mathrm{iss} 1 / 3$ 


\section{When We See Us: Coming 2 America and the Intricacies of Black Representation and Diasporic Conversation}

\section{Overview}

Coming 2 America (2021), directed by Craig Brewer (Hustle \& Flow, Dolemite Is My Name), is the three-decades-later sequel to the comedy classic Coming to America (1988), directed by John Landis (National Lampoon's Animal House, The Blues Brothers, Trading Places). Popular among an increasingly diverse audience since its release, Coming to America (CTA) and its characters, comedic voice and narratives about Africans and Black Americans are now encoded into the cultural canon. In CTA, Eddie Murphy played the role of Prince Akeem, the inconsequential monarch of the fictitious country of Zamunda, an "African" nation pulsing with fantastical royal pomp and vibrant visual aesthetics. The story finds Akeem in desperate straits over the future of his nation after his paternalistic father dies shortly after lambasting his son's procreative failure as a father of only daughters. This is problematic since, by tradition, women cannot occupy the seat of power in Zamunda.

Upon his father's death, ascendant King Akeem sets out to retrace his journey to Queens, New York, where at age 21 - while posing as a commoner university student - he fell in love with Black American princess Lisa McDowell, fast food franchise heiress-rejecting the arranged marriage awaiting him back home. In the Coming 2 America $(C 2 A)$ sequel, a more mature Eddie Murphy, once again in the role of Prince Akeem, hopes to find and bring to Zamunda a recently discovered American-born adult son, New Yorker Lavelle Junson. As the heir of the king, Lavelle presumably will both restore Akeem's masculine pride and save his father's nation from the predation of rival ruler General Izzi, played by Wesley Snipes, who seeks a politically advantageous marriage between one of his and Akeem's children. The film leans hard into the current mood for Black 1980s nostalgia but misses opportunities to evolve comedic practices to reflect the more informed and sophisticated contemporary vernaculars of Black diasporic culture. It does, however, appeal-unevenly_for mutual understanding, or perhaps simply fresh dialogue, between continental Africans and American-born descendants of Africa. 


\section{A Different World}

Coming to America (1988) was a significant moment in cinema history. For the first time, an Africa conceived as wealthy, independent, and proud was portrayed in a Hollywood movie fronted by a Black cast and conceived by a Black star. The film also centered an upwardly mobile, self-made Black American family. This feat alone was reason enough for much of the Black filmgoing audience to support it. But it was Murphy's singular élan, comedic skill and broad appeal that vaulted the movie to cult status. While it received middling reviews - largely from the mainstream press, and its share of criticism upon release - it certified Murphy as a character actor and left its mark as a comedy standard. Capitalizing on the first film's popularity and the current taste for throwback Gen X culture (see: E!'s "A Different World" Reunion Road Trip series or Lena Waithe's "Boomerang" BET series based on Murphy's popular 1992 film), the team behind Coming 2 America, the cleverly titled follow-up, situates the sequel squarely within familiar constructs.

The original film's framing of its Black male characters managed to confront certain tropes. Stereotyping African men as either unsophisticated innocents (see: Barbershop films) or suave, regal fantasies (e.g., Beauty Shop and Phat Girls) has been common in Black American-focused film. In more mainstream Hollywood movies, African men generally have been featured in war or slavery stories, although these representational perspectives sometimes overlap. Yet despite shortcomings in his film's character development, Murphy brought to the screen a set of portrayals of Black men - introspective prince, insensitive but loving king, spoiled American business heir - that rarely had been presented in a big-budget Hollywood film. While several of these characterizations reflected and captured a genuine Black American curiosity about African heritage, the filmmakers relied on common falsehoods and divisive jokes about African identity, slavery and gender roles.

A more generalized invocation, even romanticization, of royal African-ness looms within the Black American cultural and intellectual imagination in the vernaculars and political discourses of personhood and Black pride, 1960s-1970s soul music, and hip-hop culture. Rap of the 1980 s and early 1990s, building on the path-breaking musical and social dialogues of the soul era, played a critical role in advancing notions of regal African heritage (Queen Latifah, the Universal Zulu Nation) antidotal measures against racial self-hate that often meshed Afrocentrism with religious and liberation ideologies to establish self-determined identity frameworks, not to mention new music, fashion, art, dance and linguistic 
modalities. Bennett and Morgan (2011, p.184) state that such "hip-hop pioneers adhered to belief systems that upheld basic human equality and that explicitly denounced constructions of race and racist activities to separate and hierarchically situate human beings." However, a clearer understanding of African histories and cultures - myriad, rich, expansive and diverse - began to deepen in the ensuing decades, as Black academic discourses and language entered the mainstream lexicon (and as scholars such as hooks (1996), Gates (2014), Crenshaw (2017), Dyson (2008) and most recently Hannah-Jones (2014) became well-known figures) and converged with emergent social perspectives that foreground inclusivity, progressivity and cultural representation and literacy.

These shifts, in process throughout the $20^{\text {th }}$ and $21^{\text {st }}$ centuries, are evident across multidisciplinary Black cinema. While Black filmmakers have been producing nuanced independent and documentary films and series that center the lived experiences of diasporic Black people for decades, a cursory survey of works released in just the last 10 years yields critical examples such as High on the Hog, the 2021 Netflix documentary series connecting Black America's culinary histories and traditions to its African roots through foodways, commerce and the tentacles of the slave trade; Through a Lens Darkly (2014), a critical rumination of Black visual representation inspired by scholar and photographer Deborah Willis's book "Reflections in Black: A History of Black Photographers, 1840 to the Present"; director Dee Rees's Pariah (2011), the coming-of-age story of a queer Brooklyn teen; and Ava DuVernay's Middle of Nowhere (2012), a contemplative study of a woman's burgeoning agency.

The original Coming to America, therefore, emerged postBlaxploitation and pre-technology, before streaming, social media, digital screening platforms and Black film festivals would make casual screening of critical works such as Senegalese cinema legend Ousmane Sembene's Black Girl, for example, a possibility for general audiences, awakening them to the diversity of global Black cinema and its range of gifted practitioners. This era, the Black "New Wave" as described by film scholar Bogle (2016), also saw the rise of independent directors and landmark works by L.A. Rebellion's Julie Dash (Daughters of the Dust) and Charles Burnett (To Sleep with Anger), among other key filmmakers, and seminal films such as cinematographer/director Ernest Dickerson's Juice and iconoclast Spike Lee's Do the Right Thing. The year 1988, when Coming to America hit theaters, saw the release of Lee's Black college class-andcolorism opus, School Daze, and Keenan Ivory Wayans's Blaxploitation sendup, I'm Gonna Git You Sucker. Within this dynamic context, Coming 
to America entered a landscape brimming with evolving cultural and sociopolitical rhetorical currents and fresh examinations of Black screen representations that confronted long held conventions of identity, beauty and sexuality, and asserted new paradigms of freedom, gender and power.

\section{Wakanda and the Second Coming}

Comparisons between the fictional Zamunda and Black Panther's Wakanda (see Bowles 2018; Eckhardt 2018) circulated widely in the years leading up to the release of Ryan Coogler's 2018 Marvel juggernaut and in anticipation of Coming 2 America's release (with even Black Panther star Lupita Nyong'o jokingly posting on social media about hopping a flight between the imaginary African nations). Both films have influenced the other, and it is clear the elaborate and award-winning costumes and set design of Black Panther had a significant impact on Coming 2 America's production team (brilliant costume designer Ruth E. Carter, who won an Oscar for Black Panther, designed the costumes for Murphy's second Coming). Yet while the aesthetic influence of Black Panther is evident in the filmmaking, the Afrofuturist, Pan-Africanist perspective so essential to Black Panther's outlook is absent in Zamunda. Well into the next millennium, Coming 2 America appeals to certain regressive "dark continent" Hollywood tropes and posits a reductive framing of sexualities and gender hierarchies.

Still, the film's storyline features some important elements. The misunderstandings at the heart of the tension between the Zamundans and Lavelle's African American family are grounded in mischaracterizations and disinformation that cut both ways. Black Panther's Erik Killmonger/N'Jobu N'Jadaka, the dual-spirited lost son of Wakanda, was the embodiment of (male) Black American rage, consumed by the loss of his familial ties and royal inheritance and his consignment to America's violent streetscape. Likewise, Akeem's son, Lavelle (Jermaine Fowler), approximates the aimless restlessness of a man who not only misses the guidance of his father but also the sense of purpose and grounding imparted by a secure cultural identity. Like Killmonger, and thus African American men at large, his spirit yearns to know himself fully, to wholly inhabit his identity. Despite precious screen time wasted on contrasting stereotypical representations of "cool" black American-style posture and carriage versus the writers' idea of apparently more staid "African" versions, Fowler is given space to shade in Lavell's outline - he wryly confronts the ironies of his gentrifying New York neighborhood and its effects on his life options as well as the pain of growing up without his 
father. These are meaningful concepts to mine, but the film touches upon them incompletely, leaving viewers to construct a comprehensive narrative. And as is typical in male-centric storylines, such compassion extends only to Lavelle; his mother, Mary Junson, and other female characters are rendered in one-dimensional sketches.

\section{The Western Gaze \& the Queenmother}

If the film exercises a degree of nuance in its portrayals of men (although the talented Wesley Snipes's General Izzi lacks all subtlety), it outright invokes well-worn stereotypes when it comes to some of the female characters. Much has changed for Black women in terms of screen representation since Coming to America debuted in 1988. Thanks to the expansion of opportunity for talented Black producers, writers and directors (Regina King, Dee Rees, Kasi Lemmons, Issa Rae among them), audiences have experienced more humanistic and realistic portraits of Black women in their ranges of interior and aesthetic glory. Yet the C2A sequel's filmmakers rely upon misguided characterizations in shaping several female players. Brewer and his writing team attempt to remix the dynamic among the royal family, surrounding Akeem with a throng of daughters. Meeka (Kiki Layne), the eldest, bristles at the gendered traditions prohibiting her from a ruling position. Layne is given little room to flex beyond combat training scenes intended to convey her power; when Lavelle and his family show up in Zamunda, she can do little more than glower until she becomes her half-brother's confidante, assisting him through a series of tests meant to prove his intellect, valor and worthiness of the seat of power. The younger daughters have little to do.

General Izzi's politically driven offering of his daughter Bopoto to marry Akeem's son is one of the film's most misogynistic moments, which finds Lavelle, the King and the General himself leering as Bopoto (Teyana Taylor) performs an inexplicably provocative American-style dance number by way of introduction. It is a naked, pointless showcase of Taylor's dance talent and reads as a halfhearted effort to one-up the most famous scene from the original film, when Izzi's sister Imani (Akeem's intended arranged wife, played by Vanessa Bell Calloway) is tested for wifely fitness by complying with any of the Prince's random commands, including to bark like a dog. While watching Taylor's scene play out, it is difficult to discern whether it is "Meeka" or Layne herself who is registering disgust. As in the first film, the African bride is exoticized and sexualized, stripped of both agency and cultural grounding.

Bell Calloway, the accomplished stage and screen actress, spoke out just before the recent film's release about the colorism in casting that 
she believes relegated her to the small if memorable role of Imani rather than the lead part of Lisa McDowell, for which she auditioned [Araujo 2021]. Colorism indeed relegated Lisa's sister, Patrice (Allison Dean), a deep-hued beauty, to the second-fiddle position in the original film, openly complaining that her lighter-skinned sister "gets all the good ones." The sequel positions Lavell's mother, Mary (comedic star Leslie Jones), in a similar if more aggressively stereotypical position, as Lavell's very conception is revealed to be the result of a drugged sexual assault of then-Prince Akeem. This is played for laughs with the implicit message that she must resort to coercive encounters to satisfy her sexual desires.

The framing of Mary's sexuality is rooted in the "discourses of sexual behavior" reflected in slave societies, that "dictated the nature of sexual performance publicly and privately" (Fuentes 2018). The ubiquity of such stereotypes speaks to the long history of films and TV shows designating Black women of certain hues and sizes as desexed or oversexed, lonely, or angry and aggressive. Jones literally is credited in her filmography in multiple roles simply as "Angry Woman," "Angry Subway Patron," "Chatty Woman" - not to mention as the voice of an "Angry Bird" in the animated film of the same title (IMDB Filmography, 2021). Thus, her character's framing is not a departure; it is in fact a reflection of the entrenched nature of colorism and its pernicious effects on the representational idioms of Black femaleness within cinema and on the career possibilities of many Black women performers. In Carter's elaborate African-style wardrobe, Jones seems to enliven and reveal greater depth and possibility. What might she offer in the hands of Black women writers?

In the original CTA film, Lisa McDowell's family is a warm portrait of Black American family life, though the mother figure is conspicuously absent. Likewise, the extraordinary and accomplished actress Madge Sinclair was a regal yet immaterial presence as Akeem's mother, Queen Aoleon. Although Sinclair died in 1995, the filmmakers chose not to recast her role in the sequel and mention the queen only in passing near the film's end. The suggestion here and throughout the films is that Black women, no matter their status globally, occupy diminished social roles, limited power and prescribed potentialities.

In Coming 2 America, Lisa ceremonially occupies the Zamundan queen's throne with a palpable yet unmoving frustration. The filmmakers frame Lisa's subsumed independence as petulance as she uses the only power the writers envision for her - her sexual influence - in her standoff with Akeem over Meeka's right to rule. Lisa seems most alive when teasing a burgeoning friendship with fellow New Yorker Mary, 
though it only rises to the surface in moments of drunken silliness. In choosing to lean into narratives of female powerlessness rather than reference historical examples like Queen Nzingah, visionary ruler of $17^{\text {th }}$ century Angola, or recent Liberian President Ellen Johnson Sirleaf, the filmmakers miss a critical opportunity to expand the Hollywood frame. Wakanda's Queen Ramonda (Angela Bassett), though she does not lead her nation, embodies dignity and influence and is addressed throughout Black Panther as "Queenmother" - a term of historical significance within matrilineal precolonial social order (Farrar 1997). To understand these histories makes it difficult to take even casual, humorous pleasure in the diminished representational possibilities of the film's main female characters.

\section{To Be Loved...}

At its core, Coming 2 America, like its predecessor, is a love story. This is where the film succeeds best, marking a departure from the original film in reversing (and perhaps modernizing) the romantic setup between the American-born man (Lavelle) and African woman, royal groomer Mirembe (played by South African Nomzamo Mbatha), who have been falling for each other over conversational styling sessions in which they explore common dreams and exchange romantic sparks. Mirembe wishes to open her own barbershop in Zamunda, where women apparently cannot be business owners; again the filmmakers fail to either probe specific cultural barriers limiting Zamundan women's career possibilities or to highlight the real-world emergence of women entrepreneurs across the continent (Anyansi-Archibong 2021). Yet the relationship between Mirembe and Lavelle is one for which to cheer. Their connection feels genuine, and the next-generation actors breathe air into the familiar and represent a pairing of emotional equals more convincing than the marriage between African royalty Akeem and Queens-raised Lisa.

After Lavelle has successfully completed his royal training, he overhears a conversation between his father and General Izzi positioning his welcome to Zamunda as a mere tool for the marriage arrangement. He angrily flees the country with Mirembe and his Queens family, leaving his father to piece together events and track the couple to New York to make amends. They make up, everyone returns to Zamunda, and another grand, feel-good wedding (where at last African musicians make a brief appearance) closes the film. A moment during the finale, in which Akeem changes course and instead offers the throne to his daughter, Princess Meeka, feels a bit like a hollow victory, since she primarily has served as a side player throughout the film. 


\section{Concluding Comments}

Black filmmakers, since Oscar Micheaux made his first picture more than a century ago, have created powerful works probing prismatic sexualities, identities, familial and relational structures, power dynamics, interiorities and complex lived experiences in the form of comedies, satires, documentaries and dramas. While its prequel made its mark on cinema, Coming 2 America largely fails to advance realistic, specific African representation. The film turns a critical eye toward certain conventions of Black class aspiration but yields to outmoded gender hierarchies even as it belatedly recognizes a female leader. Yet, as powerfully demonstrated by the work of contemporary directors such as Jordan Peele (Get Out), Ava DuVernay, Ryan Coogler and Shaka King (Judas and the Black Messiah), among a cohort of distinguished predecessors, it is clear that Black audiences and the diverse global audiences that consume Blackfocused cinema and media, crave historical accuracy and authentic, humanizing stories - even within Hollywood's architecture.

The tempest over realistic representation of Afro-Latinx people in director Jon M. Chu's In the Heights (2021) that forced public discussion and reckoning about global colorism should dispel any notions that such issues can be shrugged off or ignored, no matter the cinematic form or how well-intentioned or accomplished the filmmaker - an indisputable testament to the power of the film medium. And films and televisual content, while often holding up mirrors that reflect the changing character of economies and societies, are themselves commercial products. As scholar/critic bell hooks (1996, p. 3), in her film studies tome Reel to Real: Race, Sex and Class at the Movies, wrote:

The fact that some folks may attend films as 'resisting spectators' does not change the reality that most of us, no matter how sophisticated our strategies of critique and intervention, are usually seduced, for at least a time, by the images we see on the screen. 


\section{References}

Anyansi-Archibong, Chi (2021), "Future of Women Entrepreneurs in Africa. In: The Foundation and Growth of African Women Entrepreneurs," Palgrave Studies of Entrepreneurship in Africa, $155-68$.

Araújo, Keko (2021), "Actress Vanessa Bell Calloway Says She Didn't Get Lead Role in 'Coming to America' Because She Was Too Dark," Black Enterprise, (accessed on August 5, 2021), [available at: https://www.blackenterprise.com/actress-vanessa-bell-callowaysays-he-didnt-get-lead-role-in-coming-to-america-because-she-wastoo-dark/]

Bennett, Dionne and Marcyliena Morgan (2011), "Hip-Hop \& the Global Imprint of a Black Cultural Form," Daedalus, the Journal of the American Academy of Arts \& Sciences, 140 (2), 176-96. https://doi.org/10.1162/DAED a 00086

Bogle, Donald (2016), Toms, Coons, Mulattoes, Mammies, and Bucks: An Interpretive History of Blacks in American Films, New York and London: Bloomsbury Academic.

Bowles, Terri P. (2018) "Diasporadical: In Ryan Coogler's 'Black Panther,' Family Secrets, Cultural Alienation and Black Love," Markets, Globalization \& Development Review, 3 (2), Article 7. https://doi.org/10.23860/MGDR-2018-03-02-07

Crenshaw, Kimberlé W. (2017), On Intersectionality: Essential Writings, New York: The New Press.

Dyson, Michael Eric (2008), The Michael Eric Dyson Reader, London: Hachette.

Eckhardt, Giana M. (2018) "Black Panther: Thrills, Postcolonial Discourse, and Blacktopia," Markets, Globalization \& Development Review, 3 (2), Article 6. https://doi.org/10.23860/MGDR-2018-03-02-06

Farrar, Tarikhu (1997), "The Queenmother, Matriarchy and the Question of Female Political Authority in Precolonial West African Monarchy," Journal of Black Studies, 27 (5), 579-97. https://doi.org/10.1177/002193479702700501

Fuentes, Marisa J. (2018), "Reading the Specter of Racialized Gender in Eighteenth-Century Bridgetown, Barbados," Sexuality \& Slavery: Reclaiming Intimate Histories in the Americas, Ramey Berry, Daina and Harris, Leslie M., eds., Athens, Georgia: The University of Georgia Press, 49-65.

Gates, Jr., Henry Louis (2014), The Signifying Monkey: A Theory of African American Literary Criticism, New York: Oxford University Press. 
Hannah-Jones, Nikole (2014), "Segregation now," The Atlantic, 313 (4), 58-69.

hooks, bell (1996), Reel to Real: Race, Sex and Class at the Movies, New York and London: Routledge.

IMDB Filmography (2021), Leslie Jones, IMDB, (accessed on July 27, 2021), 